Sari Pediatri, Vol. 2, No. 1, Juni 2000 


\title{
Hemartrosis pada Hemofilia
}

\author{
Djajadiman Gatot*, Setyo Handryastuti**
}

\begin{abstract}
Hemofilia merupakan penyakit gangguan perdarahan yang bersifat herediter dengan berbagai macam manifestasi perdarahan, salah satunya ialah hemartrosis atau perdarahan sendi. Hemartrosis dapat menimbulkan masalah jangka panjang yaitu terjadinya artropati kronik. Hal ini dapat dicegah dengan tatalaksana hemartrosis secara baik dan optimal.
\end{abstract}

Kata kunci: hemofilia - artropati kronik

If emofilia merupakan penyakit gangguan perdarahan yang bersifat herediter, paling banyak ditemukan pada anak lakilaki. Salah satu manifestasi klinis perdarahan pada hemofilia adalah hemartrosis atau perdarahan sendi. ${ }^{1-}$ ${ }^{4}$ Hemartrosis akut merupakan manifestasi perdarahan yang tersering pada hemofilia berat yaitu sekitar $85 \%$ dari seluruh episode perdarahan. ${ }^{5}$ Apabila hemartrosis terjadi berulang kali, dapat menyebabkan artropati kronik yaitu kerusakan sendi. ${ }^{3}$ Sendi yang paling sering terkena adalah sendi lutut, kemudian berturutturut sendi siku, pergelangan kaki, bahu, pergelangan tangan, panggul, lengan, dan kaki. Hal ini diduga karena karena ketidakmampuan sendi lutut, siku dan pergelangan kaki yang merupakan sendi engsel menahan gerakan berputar dan menyudut baik oleh gerakan volunter maupun gerakan involunter sedangkan persendian lain yaitu sendi panggul dan bahu dapat menahan beban tubuh, gerakan menyudut, dan memutar dengan lebih mudah. ${ }^{5}$ Bila pada salah satu sendi telah terjadi hemartrosis maka kejadian hemartrosis berikutnya sebagian besar akan mengenai sendi yang sama.

Insidens dan derajat hemartrosis dipengaruhi oleh

*Kepala Subbagian Bagian Ilmu Kesehatan Anak FKUI-RSCM Jakarta (Dr. Djajadiman Gatot, SpA(K); **Peserta Program Dokter Spesialis Ilmu Kesehatan Anak FKUI/RSCM (Dr. Setyo Handryastuti)

Alamat korespondensi:

Dr. Djajadiman Gatot, $\mathrm{SpA}(\mathrm{K})$

Jl. Salemba No. 6, Jakarta 10430, Indonesia.

Telpon: (021) 319 1170. Fax.: (021) 391 4126, beberapa faktor yaitu; kadar faktor VIII atau IX yang beredar dalam sirkulasi, episod trauma dan usia pasien. Adanya antibodi atau inhibitor tidak mempengaruhi derajat dan frekuensi hemartrosis. ${ }^{6}$

\section{Patogenesis Artropati Kronik}

Pada hemartrosis, kejadian yang paling ditakuti adalah terjadinya artropati kronik hemofilia sebagai akibat terpaparnya jaringan sendi terhadap perdarahan intraartikular berulang dan berkepanjangan, sehingga mengakibatkan kerusakan sendi melalui beberapa mekanisme yang melibatkan jaringan sinovial, cairan sinovial dan kartilago artikular. Fungsi cairan sinovial berfungsi untuk lubrikasi, nutrisi jaringan sendi dan shock absorber, sedangkan fungsi membran sinovial untuk mengatur volume cairan sinovial dan membersihkan cairan sinovial dari debris antara lain darah. ${ }^{7,8}$

Faktor-faktor yang berperan dalam patogenesis artropati adalah faktor fisik baik lokal maupun umum dan faktor kimia.

\section{Faktor fisik umum}

Perdarahan intra-artikular yang berkepanjangan akan menyebabkan peningkatan tekanan intra-artikular sehingga mengakibatkan kerusakan sinovium dan destruksi kartilago artikular. ${ }^{910}$ Tekanan intra-artikular yang tinggi makin diperberat dengan posisi fleksi yang selalu terjadi pada hemartrosis sebagai refleks untuk mengurangi nyeri. 9 


\section{Faktor fisik lokal}

Pada pasien hemofilia yang tidak mendapat terapi yang adekuat, penurunan aktifitas tromboplastin di sinovium dan kapsul fibrosa akan menyebabkan hematoma tetap dalam bentuk cair dan akan terus bertambah ukurannya sehingga akan menyebabkan peningkatan tekanan intra-artikular. ${ }^{11}$ Pembentukan bekuan yang berlebihan, akibat dari hemartrosis yang melanjut tidak dapat dihancurkan secara sempurna oleh proses fibrinolitik. Organisasi dari bekuan yang tersisa akan menyebabkan pembentukan jaringan fibrosis yang berlebihan. ${ }^{12}$

Jaringan sinovial merupakan lokasi utama perdarahan sendi, Sinovium yang hiperemis dapat menjadi subyek terjadinya perdarahan berulang setelah hemartrosis yang pertama. Satu kejadian hemartrosis merupakan predisposisi terjadinya perdarahan berikutnya. Fibrosis subsinovial dan intra artikular yang menebal akan mengakibatkan fibrosis kapsular dan kontraktur sendi. ${ }^{13}$ Komposisi cairan sinovial akan terganggu dengan adanya darah, bekuan, plasmin dan enzim lisosom yang dilepaskan oleh jaringan sinovial yang meradang, hal ini akan berakibat langsung pada nutrisi kartilago artikular. ${ }^{14}$

\section{Faktor kimia}

Peran besi dalam patofisiologi artropati masih belum jelas. Stein menemukan bahwa terdapat deposit besi (siderosome) dalam sitoplasma sel sinovial, Jaringan subsinovial, dan kondrosit pada lapisan superfisial kartilago artikular. ${ }^{12}$ Ternyata siderosome dalam sitoplasma tersebut secara langsung me-nyebabkan degenerasi dini dan disintegrasi sel. ${ }^{12,15,16}$ Gangguan fisiologis sel kondrosit yang disebabkan hemartrosis berulang, gangguan fisik dan kimia dari matriks kartilago akan menyebabkan proses patologis kerusakan yang berat dari kartilago artikular pada artropati kronik. ${ }^{17}$

Proses degenerasi dan nekrosis kondrosit yang mengandung siderosome di daerah supersifisial dan bagian atas kartilago akan menyebabkan gangguan kontinyuitas permukaan sel seperti hilangnya matriks yang akan menyebabkan robekan dan rusaknya kartilago. ${ }^{18}$

Destruksi kartilago yang luas ternyata berkaitan dengan sinovium yang berpigmentasi. Telah diketahui bahwa enzim proteolitik mungkin menyebabkan degradasi kartilago dan peningkatan kadar enzim hidrolitik terutama cathepsin D yang terdeteksi di sinovium dan cairan sinovium pada persendian pasien hemofilia. Enzim tersebut mempunyai efek kemotaktik yang poten dan berperan dalam mempertahankan peradangan kronik sinovium. Cathepsin D juga menyebabkan degradasi matriks ekstraselular kartilago artikular yang pada akhirnya menyebabkan degenerasi kartilago. ${ }^{19}$

Plasmin suatu enzim proteolitik produk dari aktivasi plasminogen serum juga berperan dalam proses degenerasi sendi pada artropati kronik hemofilia. Plasmin dapat teraktivasi di cairan sendi sebagai akibat trauma sinovium dan kartilago. Kartilago dapat mengaktivasi plasminogen yang dilepaskan ke dalam sendi sebagai akibat peningkatan permeabilitas pembuluh darah sinovium setelah terjadi hemartrosis. ${ }^{20}$

Fibrosis lapisan sinovial pada persendian pasien hemofili akan mengakibatkan gangguan fungsi sel-sel sinovial yaitu fungsi sintesis dan sekresi glikosaminoglikan terutama kondroitin sulfat. Fungsi lain membran sinovial adalah sekresi asam hialuronat ke dalam cairan sendi.

Pada keadaan normal permukaan kartilago artikular dilapisi oleh asam hialuronat dan protein yang melindungi jaringan di bawahnya dari kerusakan mekanik dan enzimatik oleh sel-sel darah dan fibroblas cairan sinovial. Lapisan asam hialuronat ini tidak terdapat pada kartilago artikular pasien hemofilia. ${ }^{12}$

Secara garis besar dapat dikatakan bahwa gangguan mekanik dan kimia akan mengakibatkan kerusakan selsel sinovial dan kondrosit kartilago artikular, gangguan enzimatik tampaknya paling berperan dalam proses degradasi matriks kartilago. Patogenesis ini dapat digambarkan dalam Gambar 1.

\section{Klasifikasi Hemartrosis}

Klasifikasi hemartrosis dibedakan secara klinis dan radiologis. Klasifikasi secara klinis bermanfaat untuk menentukan tatalaksana medis sedangkan klasifikasi secara radiologis untuk menentukan tatalaksana bedah. Klasifikasi secara klinis dibagi menjadi 3 yaitu:

\section{Hemartrosis akut}

Hemartrosis akut terjadi secara cepat setelah gejala prodroma berupa rasa nyeri dan kekakuan. Sendi menjadi tegang, bengkak, keras, panas dan nyeri, sedang kulit di 


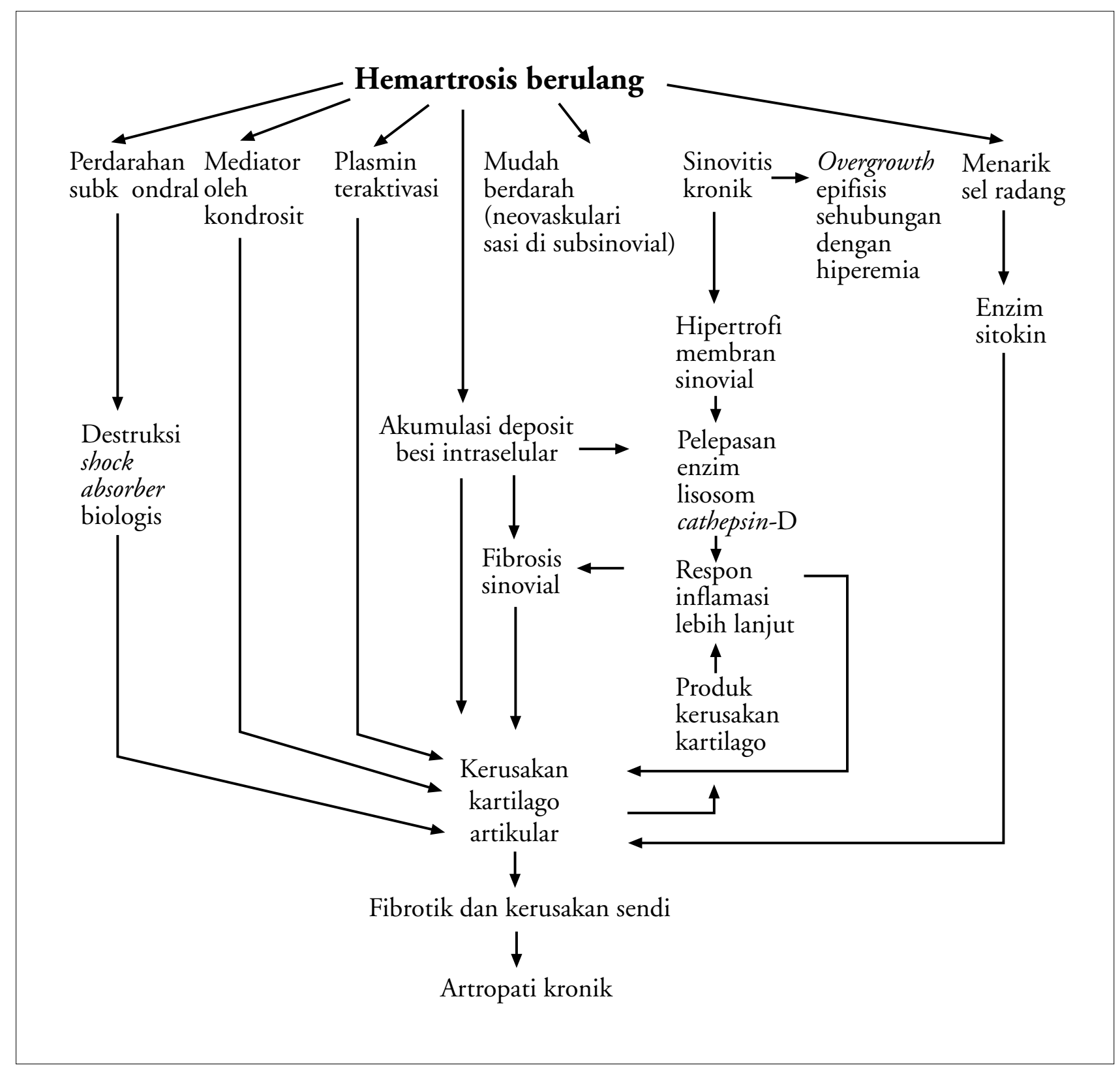

Gambar 1. Patogenesis artropati kronik hemofilia. ${ }^{21}$

atasnya mengkilat dan merah. Sendi yang terkena selalu dalam posisi fleksi dan terbatas pergerakannya oleh karena hemartrosis dan nyeri. Nyeri cepat menghilang dengan pemberian faktor pembekuan. ${ }^{22,23}$

\section{Hemartrosis subakut}

Hemartrosis subakut terjadi setelah dua kali atau lebih hemartrosis akut, meskipun telah diberikan terapi yang adekuat. Sinovium menebal dan terdapat restriksi sedang di pergerakan sendi. Nyeri bukan merupakan gejala utama tahap subakut ini. ${ }^{22,23}$

\section{Hemartrosis kronis}

Hemartrosis kronis terjadi setelah hemartrosis subakut berlangsung selama 6 bulan atau lebih. Perubahan yang progresif terjadi sampai stadium 
akhir artropati yaitu suatu keadaan fibrosis, kontraktur, oleh karena terjadi kerusakan sendi yang menyeluruh. 22,23

Klasifikasi yang dipakai berdasarkan gambaran radiologis dibagi menjadi 5 stadium, yaitu :22

\section{Stadium I}

Pada stadium I tidak terdapat kelainan tulang, hanya terdapat pembengkakan jaringan lunak di sekitar sendi. ${ }^{22}$

\section{Stadium II}

Pada stadium II biasanya bersamaan dengan stadium klinis yang disebut hemartrosis subakut. Terdapat osteoporosis terutama pada epifisis, selain terdapat pertumbuhan epifisis terutama pada sendi lutut dan siku. Integritas sendi tetap baik, tanpa adanya penyempitan ruang kartilago dan tidak terdapat kista tulang. ${ }^{22}$

\section{Stadium III}

Pada stadium III terjadi disorganisasi sendi yang tampak pada gambaran radiologis, tetapi tidak terdapat penyempitan ruang kartilago yang bermakna. Lekukan interkondilar pada sendi lutut dan trokanter ulna biasanya melebar. Pada fase ini gambaran radiologis penting yang ditemukan adalah kartilago sendi tetap utuh. Stadium ini merupakan stadium akhir artropati yang masih reversibel terhadap tatalaksana medis ${ }^{22}$

\section{Stadium IV}

Stadium IV ditandai dengan penyempitan ruang sendi dan terdapat kerusakan kartilago. ${ }^{22}$

\section{Stadium V}

Stadium V merupakan fase akhir, ditandai dengan kontraktur sendi, fibrosis sendi, ruang sendi menghilang, pembesaran epifisis yang luas dan disorganisasi hebat struktur sendi. Sendi. Pada stadium ini jarang terjadi perdarahan. ${ }^{22}$

\section{Diagnosis}

Diagnosis hemofilia ditegakkan bila dalam anamnesis ditemukan riwayat perdarahan, terutama bila dijumpai perdarahan sendi, terdapat riwayat saudara laki-laki sekandung yang menderita sakit yang sama, dan saudara laki-laki dari ibu yang menderita sakit yang sama. Pada pemeriksaan fisik dapat ditemukan gejala perdarahan, dengan gejala khas hemartrosis.

Kelainan sendi dapat ditemukan dalam bentuk hemartrosis akut, subakut dan kronik. Pada gambaran radiologis tulang dapat ditemukan gambaran bervariasi dari pembengkakan jaringan lunak sampai fibrosis dan disorganisasi sendi yang berat. Pada pemeriksaan laboratorium didapatkan masa perdarahan memanjang, jumlah trombosit normal, PTT memanjang, PT normal, dan pada TGT umumnya didapatkan defisiensi AHG pada hemofilia $\mathrm{A}$, sedangkan defisiensi plasma tromboplastin component (PTC) ditemukan pada hemofilia B. ${ }^{1,2,5,22}$

\section{Tatalaksana}

Tatalaksana artropati hemofilik memerlukan kerjasama yang baik antara ahli hematologi dan bedah ortopedi, dan dibagi menjadi:

\section{Tatalaksana medis}

\section{Kontrol perdarahan}

Tujuan utama tatalaksana medis pada hemartrosis akut adalah menjamin hemostasis dengan cara pemberian terapi pengganti (replacement therapy $)^{5,22}$ Tujuan tatalaksana medis primer lainnya untuk menghilangkan nyeri, mempertahankan dan memperbaiki fungsi sendi, serta mencegah artropati kronik., ${ }^{5} 22$ Pada hemartrosis akut, jika perdarahan dapat dikontrol sejak awal, hanya sedikit perdarahan yang menekan sendi sehingga tekanan intra-artikular akan berkurang. Faktor yang berpengaruh ialah: luasnya hemartrosis, jumlah atau kadar faktor yang beredar, adanya antibodi, waktu paruh faktor yang diberikan. ${ }^{5,22}$

\section{Terapi pengganti}

Umumnya untuk terapi pengganti digunakan kriopresipitat atau lyophilized human $A H G$ untuk hemoflia A, tetapi dapat pula digunakan fresh frozen plasma (FFP). Plasma, kriopresipitat dan konsentrat AHG hanya mengandung sedikit faktor IX, hingga untuk hemofilia B diberikan FFP atau konsentrat faktor IX. ${ }^{5,22}$ Dosis faktor pembekuan yang diberikan dihitung menggunakan hubungan antara peningkatan konsentrasi plasma faktor pembekuan dan dosis dalam unit per kilogram. Patokan umum adalah 1 unit faktor VIII per 
kilogram berat badan akan menaikkan aktifitas faktor VIII pasien sebesar 2\%; sedangkan 1 unit faktor IX akan menaikkan aktifitas faktor IX sebesar 1,5\%., 22 Waktu paruh faktor VIII pada hemofilia sekitar 12 jam dan faktor IX kira-kira 18 jam $^{5,22,23}$ Hal itu berarti 12 jam setelah pemberian infus faktor VIII, kadarnya akan menurun menjadi setengah kadar inisial, sehingga diperlukan infus setengah dosis inisial setiap 12-18 jam untuk mening-katkannya ke kadar inisial. ${ }^{5,22}$ Untuk penanganan adekuat hemartrosis dibutuhkan kadar faktor pembekuan dalam plasma $30-50 \% .{ }^{24}$ Umumnya untuk hemofilia A dipakai dosis faktor VIII 15-25 unit/ $\mathrm{kg}$ berat badan atau 3-4 kantong/10 kg bila meng-gunakan kriopresipitat. ${ }^{24}$ Untuk hemofilia $\mathrm{B}$ digunakan konsentrat faktor IX dengan dosis 30-50 unit $/ \mathrm{kg}$ berat badan. Terapi ini dapat diberikan pada pasien rawat jalan, diulangi setiap 24-48 jam, jika perdarahan belum terkontrol. ${ }^{22}$ Biasanya untuk hemartrosis dibutuhkan terapi 27 hari. $^{24}$

\section{Analgesik}

Pemberian analgesik dapat mengaburkan gejala perdarahan sendi yang terjadi. ${ }^{24}$ Disamping itu obat yang mengandung aspirin, guaiakolat dan antihistamin diketahui menghambat agregasi trombosit dan memper-panjang masa perdarahan pada pasien hemofilia, ${ }^{24}$ oleh karena itu pasien harus diingatkan untuk tidak menggunakan obatobatan tersebut. Bila terpaksa dapat digunakan penghilang rasa nyeri seperti propoksifen, asetaminofen, ibuprofen, meperidin, kodein, petidin atau metadon sebagai alternatif. ${ }^{5,22,25}$

\section{Obat anti inflamasi}

Pada hemartrosis akut dapat digunakan kortikosteroid dengan dosis (prednison) 1-2 mg per kilogram berat badan selama 3-5 hari dan tidak melebihi 14 hari untuk sinovitis kronis. ${ }^{22}$ Pada degenerasi sendi yang telah menetap dan adanya sinovitis persisten, injeksi steroid intra-artikular dapat menolong membebaskan rasa nyeri, tetapi pemakaian-nya harus dilindungi terapi pengganti dengan faktor yang sesuai. ${ }^{26}$ Obat anti inflamasi lain seperti indometasin, fenilbutazon sangat berbahaya digunakan karena menghambat fungsi trombosit. ${ }^{22}$

\section{Obat antifibrinolitik}

Penggunaan asam E-aminocaproic dan asam traneksamat untuk mencegah hemartrosis belum jelas manfaatnya. Secara teoritis obat antifibrinolitik mungkin malah berbahaya digunakan pada hemartrosis, karena bekuan yang terbentuk akibat asam E-aminocaproic dan asam traneksamat tidak dapat diabsorbsi sampai 6 bulan. Fibrosis dan destruksi sendi mungkin meningkat selama periode ini dan dapat mengakibatkan artropati berat. Penggunaan obat ini tidak dianjurkan dan mungkin merupakan kontraindikasi untuk artropati hemofilia. ${ }^{22}$

\section{Tatalaksana ortopedi non bedah}

Sebagai tambahan untuk terapi pengganti dapat digunakan kompres es pada sendi yang terkena selama 15 menit setiap 1-2 jam selama 48 jam pertama, dan sendi dibebat atau diimobilisasi kurang lebih selama 24 jam, serta anggota badan yang terkena ditinggikan untuk menurunkan tekanan hidrostatik vena. Fisioterapi bertahap dapat diberikan setelah 48 jam. ${ }^{23}$ Dalam waktu singkat setelah diberikan terapi pengganti, nyeri akan terkontrol dan dalam waktu 24 jam gerakan sendi dapat membaik. ${ }^{22}$

Aspirasi pada hemartrosis akut secara teoritis dapat dilakukan untuk mengeluarkan produk darah dari sendi... $22,27,28$ Umumnya tindakan ini dipertimbang-kan pada hemartrosis berat yang ditandai adanya distensi pada kapsul sendi. ${ }^{24}$ Bila akan dilakukan aspirasi, tindakan ini harus dilakukan dalam waktu 24 jam sejak awal perdarahan, sebelum terjadi pembekuan, dan terlebih dahulu diberikan terapi pengganti, serta memperhatikan sterilitas tinda-kan. ${ }^{5,22}$ Apabila dengan pemberian faktor pem-bekuan masih terjadi hemartrosis (tiga kali berturutturut dalam waktu 60 hari) maka tindakan sinovektomi medikal dengan injeksi asam osmik, rifampisin atau radiokoloid perlu dipertimbangkan..$^{22}$

Jika terjadi hemartrosis subakut, pengobatan bertujuan mencegah atrofi otot, mempertahankan gerakan sendi, mengontrol hemartrosis ulangan, dan membuat aktifitas pasien senormal mungkin. Dapat digunakan gabungan terapi profilaksis 6-8 minggu dan fisioterapi aktif. 5,22,29

\section{Tatalaksana bedah orthopedi}

Selain tatalaksana hematologi, pemakaian alat bantu ortopedi bersamaan dengan fisioterapi yang bertujuan 
Sari Pediatri, Vol. 2, No. 1, Juni 2000

melindungi sendi dan memperbaiki kontraktur jaringan lunak dapat menghindarkan tindakan bedah. ${ }^{30}$

Indikasi bedah pada pasien hemofilia adalah $:^{30}$

1. Hipertrofi sinovium yang bersifat kronik dan progresif yang disebabkan hemartrosis berulang dan tidak terkontrol dengan pemberian terapi pengganti.

2. Kontraktur jaringan lunak yang berat yang tidak membaik dengan tata laksana ortopedi non- bedah.

3. Deformitas sendi berat yang membutuhkan osteotomi.

4. Pseudotumor yang terus membesar meski-pun telah diberikan terapi pengganti dan radioterapi.

5. Infeksi kronik pada ekstremitas (amputasi)

6. Artritis yang berat dengan nyeri dan perdarahan (artroplasti sendi total)

\section{Kesimpulan}

Hemartrosis merupakan manifestasi klinis perdarahan yang tersering pada hemofilia berat, bila tidak diberikan tatalaksana yang adekuat maka proses akan berlanjut menjadi artropati kronik. Pemahaman mengenai patogenesis, diagnosis dan tatalaksana hemartrosis dapat mencegah hal tersebut sehingga pasien hemofilia berat dapat tumbuh dan berkembang secara normal.

\section{Daftar Pustaka}

1. Montgomery RR, Scot JP. Hemostasis: Disease of the fluid phase. Dalam: Nathan DG, Oski FA, penyunting. Hematology of infancy and childhood. Edisi ke-4. Philadelphia: Saunders, 1993; h. 1605-50.

2. Corrigan JJ. Haemorragic disorder. Dalam: Behrman RE, Kliegman RM, Nelson WE, Vaughan III VC, penyunting. Nelson textbook of pediatrics. Edisi ke-15. Philadelphia: Saunders, 1996; h. 1424-7.

3. Hilgartner MW, McMilan CW. Coagulation disorders. Dalam: Miller DR, Pearson HA, Bachner RL, penyunting. Smith's blood diseases of infancy and childhood. Edisi ke-4. Saint Louis, 1978; h. 771-90.

4. Robert HR, Jones MR. Hemophilia and related conditionscongenital deficiencies of prothrombin (factor II), factor $\mathrm{V}$ and factors VII to XII. Dalam: Williams WJ, Beutler E, Erslev AJ, Lichtman MA, penyunting. Hematology. Edisi ke-4. New York: McGraw-Hill, 1991; h. 1453-72.

5. Carvell JE, Duthie RB, Management of the hemophilic knee. Dalam: Insall JN, penyunting. Surgery of the knee. Edisi ke-
1. New York: Churchill Livingstone, 1984; h. 744-74.

6. Biggs R. The treatment of hemophilia A and B and von Willebrand's disease. Oxford:Blackwell Scientific Pub, 1978.

7. Salter RB. An introduction to orthopaedics, fractures and joint injuries, rheumatology, metabolic bone disease and rehabilitation. The musculoskeletal system. Edisi ke-2. Philadelphia: Williams and Wilkins, 1985; h. 209-11.

8. Turek SL. Orthopaedics principles and their application. Edisi ke-4. Philadelphia: JB Lippincott, 1984; h.44451.

9. Mc Carty DJ. Selected aspects of synovial membrane physiology. Arthritis Rheum 1974; 17:289.

10. Sokoloff L. Biochemical and physiological aspects of degenerative joint diseases with special reference to hemophilic arthropaty. Ann N Y Acad Sci 1975; 240:285.

11. Key JA. Hemophilic arthritis. Ann Surg 1982; 95:198.

12. Stein $H$. The interrelationship of synovium and articular cartilage. J Bone Joint Surg 1975; 57:282.

13. Roy S, Chadially FN. Sinovial membrane in experimentally produced chronic hemarthrosis. Ann Rheum Dis 1969; 28:402.

14. Luck JV. Articular cartilage. Responses to destructive influences. Dalam: Bassett CAL, penyunting. Cartilage degradation and repair. Washington DC: National academy of sciences, 1967; h. 143.

15. Roosendaal G, Mauser-Bunschoten EP, De Kleijn P, et al. Synovium in haemophilic arthropaty. Haemophilia 1998; 4:502-5.

16. Rodriguez-Merchan EC. The destructive capabilities of the synovium in the haemophilic joint. Haemophilia 1998: 4:506-10.

17. Robinson HJ, Granda JL. Prostaglandin in synovial inflammatory disease. Surg forum 1974; 25:476.

18. Brighton CT, Bigley EC, Smolenski BI. Iron induced arthritis in immature rabbits. Arthritis Rheum 1970; 13:849.

19. Storti E, Traldi A, Tossati E, et al. Synovectomy a new approach to hemophilic arthropaty. Acta Haematol 1969; 41:193.

20. Lack CH. Chondrolysis. Ann Phys Med 1961; 6:93.

21. Stein H, Duthie RB. The pathogenesis of chronic haemophilic arthropathy. J Bone Joint Surg 1981; 4:63.

22. Arnold WD, Hilgartner MW. Hemophilic arthropathy current concepts of pathogenesis and management. J Bone and Joint Surg 1977; 59A:277-305.

23. Gilchrist GS. Congenital and acquired bleeding disorders. Dalam: Burg FD, Ingelfinger JR, Wald ER, penyunting. Current pediatric therapy. Edisi ke-14. Philadelphia: Saunders, 1993; h.257-67.

24. Anonymous. Hemophilia. Dalam: Wickand EH, penyunting. Tachdjian pediatric orthopedics. Edisi ke2. Philadelphia: Saunders, 1990; h.1494-1512.

25. Hasiba U, Scranton PE, Lewis JH, et al. Efficacy and safety of ibuprofen for hemophilic arthropaty. Arch Intern Med 1980; 140:1583-5.

26. Ribbans WJ, Philip M, Stock D, et al.Haemophilic ankle problems: orthopaedic solutions. Haemophilia 1995; 1:91-6.

27. Petersson C. Orthopedic treatment. Hemophilia. Sweden. Pharmacia Plasma Product, 1994: 76-81.

28. Ingram GIC, Mathews JA, Bennett AE. A controlled trial 
Sari Pediatri, Vol. 2, No. 1, Juni 2000

of joint aspiration in acute haemophilic haemarthrosis. Br J Haematol 1972; 23:649-54.

29. Palazzi FF. Treatment of acute and chronic synovitis by non-surgical means. Haemophilia 1998; 4:518-23.

30. Caviglia H, Galatro G, Duhalde C. Haemophilic synovitis: is rifampicin an alternative. Haemophilia 1998; 4:514-7.

31. Siegel HJ, Luck JV, Siegel ME, et al. Hemarthrosis and synovitis associated with hemophilia: clinical use of $\mathrm{P}$ 32 chronic phospate synoviorthesis for treatment. Radiology 1994; 190:257-61.
32. Erken EHW. Radiocolloids in the management of hemophilic arthropathy in children and adolescents. Clinical orthopaedics and related research 1990; 264:129-34.

33. Teigland JC, Tjonnfjord GE, Evensen SA, et al. Synovectomy for haemophilic arthropathy: 6-21 years of follow-up in 16 patients. J Intern Med 1994; 235:239-43.

34. Heeg M, Meyer K, Smid WM, et al. Total knee and hip arthroplasty in haemophilic patients. Haemophilia 1998; $4: 747-51$ 